\title{
Synthesis of Stereoisomers of Ipconazole and Their Fungicidal and Plant Growth Inhibitory Activities
}

\author{
Atsushi Ito, Toshihide SAISHOJI and Satoru KumAZAwa \\ Nishiki Research Laboratory, Kureha Chemical Industry Company, Ltd., Nishiki-machi, Iwaki 974, Japan
}

(Received November 22, 1996 ; Accepted January 24, 1997)

\begin{abstract}
Two racemic diastereomers $\mathbf{5 a}$ and $\mathbf{5 b}$, both of which are active ingredient of a seed treatment fungicide on rice, ipconazole, ( $1 R S, 2 S R, 5 R S ; 1 R S, 2 S R, 5 S R)$-2-(4-chlorobenzyl)-5-isopropyl-1-(1H-1, 2, 4-triazol-1-ylmethyl)cyclopentanol, and two other racemic diastereomers $(1 R S, 2 R S, 5 R S)-5 \mathrm{c}$ and $(1 R S, 2 R S, 5 S R)-5 \mathrm{~d}$ were synthesized, and fungicidal activity and plant growth inhibitory activity were examined. Enantiomers of $\mathbf{5 a}$ and $\mathbf{5 b}$ were prepared, and their fungicidal activities were also examined. Racemic diastereomers $\mathbf{5 a}, \mathbf{5 b}$ and $\mathbf{5 d}$ were more active than $\mathbf{5 c}$ in fungicidal activity $\left(\mathrm{EC}_{50}\right.$ value $)$ in vitro on Gibberella fujikuroi, Cochliobolus miyabeanus and Pyricularia oryzae. In plant growth inhibitory activity test for seed treatment on rice, only $\mathbf{5 d}$ was slightly active in the first sheath growth inhibition. The comparative test of enantiomers in vitro revealed that the fungicidal activities of (-)-5a and (-)-5b were higher than those of corresponding (+)-5a and (+)-5b, respectively.
\end{abstract}

\section{INTRODUCTION}

Ipconazole, $(1 R S, 2 S R, 5 R S ; 1 R S, 2 S R, 5 S R)-2-(4-$ chlorobenzyl)-5-isopropyl-1-(1H-1, 2, 4-triazol-1ylmethyl)cyclopentanol is a new seed treatment fungicide which is effective for "Bakanae" disease, brown spot and blast on rice. The fungicidal mechanism is assumed to be the inhibition of cytochrome P450-dependent C-14 demethylation (S. Kumazawa et al.: unpubl.) of the intermediate lanosterol in the biosynthesis of sterol in fungi. Ipconazole consists of a 9:1 mixture of racemic diastereomers $\mathbf{5 a}$ and $\mathbf{5 b}$. As for racemic diastereomers of ipconazole, there exist two other isomers, $\mathbf{5 c}$ and $\mathbf{5 d}$ (Fig. 1). Many papers have reported on relationship between stereochemical structure of sterol biosynthesis inhibitor and biological activity. ${ }^{1)}$ For example, uniconazole, (E)-1-(4-chlorophenyl)-4, 4-dimethyl-2( $1 H$-1, 2, 4-triazol-1-yl)pent-1-en-3-ol is more active than $Z$-isomer in fungicidal and plant growth inhibitory activities, and $R-(-)$ enantiomer of uniconazole is highly active in fungicidal activity, on the other hand, $S-(+)$ enantiomer is highly active in plant growth inhibitory activity. ${ }^{2)}$ The cis-isomer (SSF-109) of 1-(4chlorophenyl)-2-(1H-1, 2, 4-triazol-1-yl)cycloheptanol is more active than the trans-isomer in fungicidal activity, on the other hand, the trans-isomer is more active than the cis-isomer in plant growth inhibitory activity. Enantiomer (-)-SSF-109 is more active than (+)-SSF109 in fungicidal and plant growth inhibitory activities. ${ }^{3)}$
It is particularly interesting to investigate the relationship between stereochemical structure and biological activity in the viewpoint of the elucidation of the optimum threedimensional structure for the target enzyme. ${ }^{4}$ In this paper the synthesis of stereoisomers of ipconazole and fungicidal and plant growth inhibitory activities of each isomer are described.

\section{MATERIALS AND METHODS}

\section{Synthesis of Compounds}

Synthetic scheme of four azole racemic diastereomers (5) was shown in Fig. 2 along with methods A and B. Infrared (IR) spectra were recorded on a Hitachi 270-30 spectrophotometer and ${ }^{1} \mathrm{H}$ NMR were obtained with a JEOL JNM-PMX60SI (60 MHz) or a JEOL GX500 (500 $\mathrm{MHz}$ ) using tetramethylsilane as an internal standard. Optical rotations were measured with Union Giken PM-201 polarimeter.

\subsection{Methyl 3-isopropyl-2-oxocyclopentanecarboxylate} (2)

Under nitrogen atmosphere, $60 \%$ oily sodium hydride $(9.2 \mathrm{~g}, 230 \mathrm{mmol})$ was washed with hexane, and $N$, $N$-dimethylformamide (DMF) $(160 \mathrm{ml})$ was added. To the mixture methyl 2-oxocyclopentanecarboxylate (1) (30 $\mathrm{g}, 210 \mathrm{mmol}$ ) was slowly added. After stirring for $0.5 \mathrm{hr}$, isopropyl iodide $(42 \mathrm{~g}, 247 \mathrm{mmol})$ was added in one portion, and the mixture was stirred for $3 \mathrm{hr}$ at $70-80^{\circ} \mathrm{C}$.

After cooling to room temperature, the reaction mixture was poured into water and extracted with benzene. 

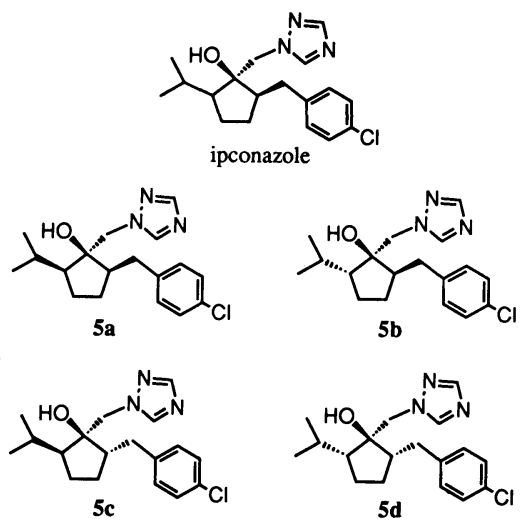

Fig. 1 Structures of ipconazole and its racemic diastereomers.
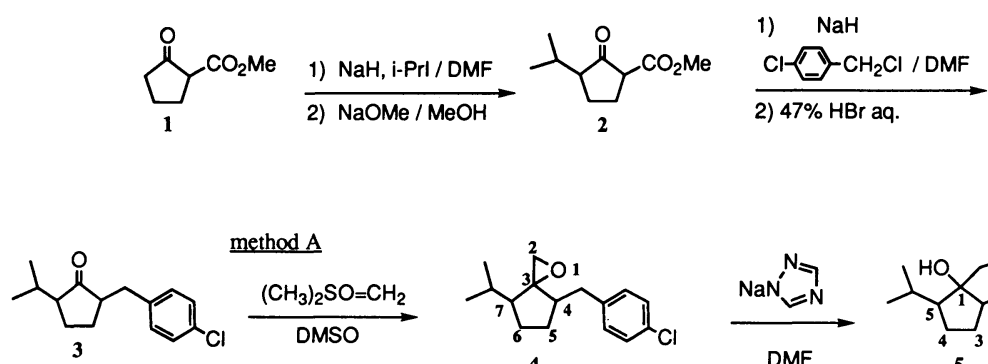

method A
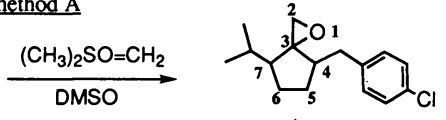

4
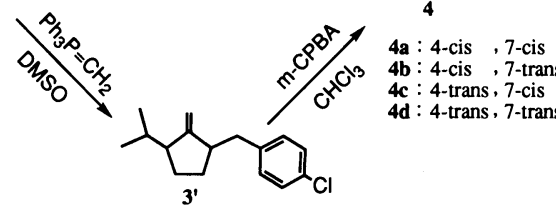

4b: 4-cis, 7 -tran $\mathbf{4 c}:$ 4-trans, 7 -cis
4d $:$ 4-trans, 7 -trans
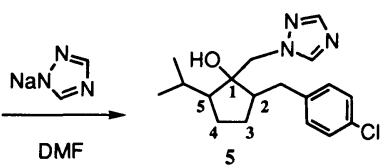

5

5a : 2-cis , 5-cis

5b : 2-cis , 5-tran

5c : 2-trans, 5 -cis

method B

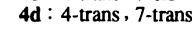

Fig. 2 Synthetic scheme of azole racemic diastereomers (5).

The benzene layer was washed with water and brine, then dried over anhydrous sodium sulfate, and evaporated under reduced pressure. Absolute methanol $(100 \mathrm{ml})$ and $28 \%$ sodium methylate in methanol $(45 \mathrm{~g}, 233 \mathrm{mmol})$ were added to the residue $(38 \mathrm{~g})$. The mixture was refluxed for $3 \mathrm{hr}$, and methanol was distilled off. Toluene $(100 \mathrm{ml})$ was added, and the mixture solvent of toluenemethanol was removed by distilling. This procedure was repeated twice to remove methanol completely.

The residue was poured into $10 \%$ acetic acid solution, and extracted with benzene. The benzene layer was washed with water and brine, then dried over anhydrous sodium sulfate. Removal of the solvent followed by distillation afforded ester (2) $(26.2 \mathrm{~g}, 67.8 \%)$, bp $84-85^{\circ} \mathrm{C}$ $(5 \mathrm{mmHg}) . \quad$ IR $\nu_{\max }^{\text {neat }} \mathrm{cm}^{-1}: 2950,1745,1720 .{ }^{1} \mathrm{H}$ NMR $\left(\mathrm{CDCl}_{3}\right) \delta \mathrm{ppm}: 0.83(\mathrm{~d}, 3 \mathrm{H}, J=6 \mathrm{~Hz}), 0.87(\mathrm{~d}, 3 \mathrm{H}, J=$ $6 \mathrm{~Hz}), 1.60-2.77(\mathrm{~m}, 7 \mathrm{H}), 3.60(\mathrm{~s}, 3 \mathrm{H})$.

\subsection{2-(4-Chlorobenzyl)-5-isopropylcyclopentanone (3)}

Under nitrogen atmosphere, $60 \%$ oily sodium hydride $(6.2 \mathrm{~g}, 155 \mathrm{mmol})$ was washed with hexane, and DMF $(150 \mathrm{ml})$ was added. To the mixture ester (2) $(26 \mathrm{~g}, 141$ mmol) was slowly added. After stirring for $0.5 \mathrm{hr}$, 4-chlorobenzyl chloride ( $25 \mathrm{~g}, 141 \mathrm{mmol})$ was added in one portion, and the mixture was stirred for $3 \mathrm{hr}$ at room temperature.

The mixture was poured into water and extracted with benzene. The benzene layer was washed with water and brine, then dried over anhydrous sodium sulfate, and evaporated under reduced pressure. The residue ( $48 \mathrm{~g}$ ) was refluxed with $47 \%$ hydrobromic acid $(160 \mathrm{ml})$ for 18 hr. After cooling to room temperature, the mixture was poured into water and extracted with benzene. The benzene layer was washed with water and brine, and dried over anhydrous sodium sulfate. Removal of the solvent followed by distillation afforded ketone (3) (19.6 g, 55.5\%), bp $143-147^{\circ} \mathrm{C}(1.2 \mathrm{mmHg})$. IR $\nu_{\max }^{\text {neat }} \mathrm{cm}^{-1}$ : 2950, 1720. ${ }^{1} \mathrm{H}$ NMR $\left(\mathrm{CDCl}_{3}\right) \delta \mathrm{ppm}: 0.77,0.80(\mathrm{~d} \times 2$, $3 \mathrm{H}, J=6 \mathrm{~Hz}), 0.93,0.97(\mathrm{~d} \times 2,3 \mathrm{H}, J=6 \mathrm{~Hz}), 1.07-3.27$ $(\mathrm{m}, 9 \mathrm{H}), 6.98(\mathrm{~d}, 2 \mathrm{H}, J=8 \mathrm{~Hz}), 7.18(\mathrm{~d}, 2 \mathrm{H}, J=8 \mathrm{~Hz})$.

\subsection{4-(4-Chlorobenzyl)-7-isopropyl-1-oxaspiro [2.4] hep- tane (4) (method $A$ )}

Under nitrogen atmosphere, $60 \%$ oily sodium hydride $(3.2 \mathrm{~g}, 80.0 \mathrm{mmol})$ was washed with hexane, and dimethylsulfoxide (DMSO) $(30 \mathrm{ml})$ was added. To the mixture trimethylsulfoxonium iodide $(17.4 \mathrm{~g}, 79.1 \mathrm{mmol})$ was added over about $0.5 \mathrm{hr}$. After stirring for $0.5 \mathrm{hr}$, ketone (3) $(10 \mathrm{~g}, 39.9 \mathrm{mmol})$ was added and the mixture was stirred for $42 \mathrm{hr}$ at room temperature.

The mixture was poured into water, and extracted with hexane. The hexane layer was washed with water and brine, and dried over anhydrous sodium sulfate.

After removal of solvent, crude oxirane (4) $(8.3 \mathrm{~g})$ was obtained as an oil. Purification of the adduct by silicagel column chromatography (hexane: ethyl acetate $=100: 1)$ gave $4 \mathbf{a}(3.2 \mathrm{~g})$ and $4 \mathbf{c}(1.2 \mathrm{~g})$. It was unable to separate oxirane isomer $\mathbf{4 b}$ and $4 \mathbf{d d}$ from unreacted ketone (3), so the ratio of oxirane isomer (4) was determined by high performance liquid chromatography (HPLC) analysis as follows : 4a $: 4 \mathbf{b}: \mathbf{4 c}: \mathbf{4 d}=61$ : $13: 22: 4$.

\subsection{4-(4-Chlorobenzyl)-7-isopropyl-1-oxaspiro [2.4] hep- tane (4) (method B)}

Under nitrogen atmosphere, $60 \%$ oily sodium hydride $(4.8 \mathrm{~g}, 120 \mathrm{mmol})$ was washed with hexane, and DMSO $(100 \mathrm{ml})$ was added. The mixture was heated to $70^{\circ} \mathrm{C}$ until the evolution of hydrogen ceased, and then cooled to room temperature. Methyltriphenylphosphonium bromide $(43.0 \mathrm{~g}, 120 \mathrm{mmol})$ was added. After stirring for $0.5 \mathrm{hr}$, ketone (3) $(20 \mathrm{~g}, 79.8 \mathrm{mmol})$ was added, and the mixture was stirred for $2 \mathrm{hr}$ at room temperature.

The mixture was poured into water, and extracted with hexane. The hexane layer was washed with water and brine, and dried over anhydrous sodium sulfate. After removal of solvent, crude olefin $\left(\mathbf{3}^{\prime}\right)(26.2 \mathrm{~g})$ was obtained as an oil. Purification of the adduct by silicagel column chromatography (hexane) gave $3^{\prime}$ (18.7 g).

To the solution of olefin $\left(3^{\prime}\right)(18.7 \mathrm{~g}, 75.3 \mathrm{mmol})$ in 
Table 1 Ratios of oxirane isomer (4) by methods A or B.

\begin{tabular}{crrrr}
\hline \multirow{2}{*}{ Method } & \multicolumn{5}{c}{ Ratio $^{\text {a) }}$} & of oxirane isomer (4) \\
\cline { 2 - 5 } & $\mathbf{4 a}$ & $\mathbf{4 b}$ & $\mathbf{4 c}$ & $\mathbf{4 d}$ \\
\hline A & 61 & 13 & 22 & 4 \\
B & 0 & 81 & 6 & 13 \\
\hline
\end{tabular}

a) Measured by HPLC analysis.

chloroform $(100 \mathrm{ml})$ was added $m$-chloroperbenzoic acid $(25.0 \mathrm{~g}, 145 \mathrm{mmol})$, and the mixture was stirred for $2 \mathrm{hr}$ at room temperature. Calcium hydroxide $(21 \mathrm{~g}, 284$ $\mathrm{mmol}$ ) was added to the reaction mixture and the mixture was stirred for $10 \mathrm{~min}$. The resulting precipitate was filtered off and the filtrate was dried up. Purification of the adduct by silicagel column chromatography (hexane : ethyl acetate $=100: 1)$ gave $4 \mathbf{b}(14.6 \mathrm{~g}), \mathbf{4 c}(1.1 \mathrm{~g})$ and $\mathbf{4 d}$ $(2.3 \mathrm{~g})$ in total $85.3 \%$ yield. The ratio of oxirane isomer (4) by method B was also measured by HPLC to compare with that of method A (Table 1).

${ }^{1} \mathrm{H} \mathrm{NMR}\left(\mathrm{CDCl}_{3}\right) \delta \mathrm{ppm}$ :

4a : $0.89(\mathrm{~d}, 3 \mathrm{H}, J=6.64 \mathrm{~Hz}), 0.90(\mathrm{~d}, 3 \mathrm{H}, J=6.64$ $\mathrm{Hz}), 1.40-1.45(\mathrm{~m}, 1 \mathrm{H}), 1.54-1.71(\mathrm{~m}, 4 \mathrm{H}), 2.06-2.10(\mathrm{~m}$, $1 \mathrm{H}), 2.24-2.28(\mathrm{~m}, 1 \mathrm{H}), 2.34(\mathrm{dd}, 1 \mathrm{H}, J=10.08,13.75$ $\mathrm{Hz}), 2.57(\mathrm{dd}, 1 \mathrm{H}, J=4.59,13.75 \mathrm{~Hz}), 2.67(\mathrm{~d}, 1 \mathrm{H}, J=$ $5.04 \mathrm{~Hz}), 2.69(\mathrm{~d}, 1 \mathrm{H}, J=5.04 \mathrm{~Hz}), 7.08(\mathrm{~d}, 2 \mathrm{H}, J=8.25$ $\mathrm{Hz}), 7.22(\mathrm{~d}, 2 \mathrm{H}, J=8.25 \mathrm{~Hz})$.

4b : $0.82(\mathrm{~d}, 3 \mathrm{H}, J=6.65 \mathrm{~Hz}), 0.88(\mathrm{~d}, 3 \mathrm{H}, J=6.65$ $\mathrm{Hz}), 1.26-1.42(\mathrm{~m}, 2 \mathrm{H}), 1.63-1.71(\mathrm{~m}, 1 \mathrm{H}), 1.73-1.79(\mathrm{~m}$, $2 \mathrm{H}), 1.96-2.03(\mathrm{~m}, 1 \mathrm{H}), 2.11-2.18(\mathrm{~m}, 1 \mathrm{H}), 2.36(\mathrm{dd}, 1 \mathrm{H}$, $J=9.85,14.10 \mathrm{~Hz}), 2.50(\mathrm{dd}, 1 \mathrm{H}, J=5.04,14.10 \mathrm{~Hz})$, $2.64(\mathrm{~d}, 1 \mathrm{H}, J=4.13 \mathrm{~Hz}), 2.90(\mathrm{~d}, 1 \mathrm{H}, J=4.13 \mathrm{~Hz}), 7.08$ $(\mathrm{d}, 2 \mathrm{H}, J=8.48 \mathrm{~Hz}), 7.22(\mathrm{~d}, 2 \mathrm{H}, J=8.48 \mathrm{~Hz})$.

$4 c$ : $0.88(\mathrm{~d}, 3 \mathrm{H}, J=6.88 \mathrm{~Hz}), 0.89(\mathrm{~d}, 3 \mathrm{H}, J=6.88$ $\mathrm{Hz}), 1.15-1.26(\mathrm{~m}, 1 \mathrm{H}), 1.42-1.50(\mathrm{~m}, 1 \mathrm{H}), 1.57-1.62(\mathrm{~m}$, $1 \mathrm{H}), 1.70-1.75(\mathrm{~m}, 2 \mathrm{H}), 1.99-2.04(\mathrm{~m}, 1 \mathrm{H}), 2.10-2.17(\mathrm{~m}$, $1 \mathrm{H}), 2.23(\mathrm{dd}, 1 \mathrm{H}, J=11.22,12.95 \mathrm{~Hz}), 2.55(\mathrm{~d}, 1 \mathrm{H}, J=$ $4.81 \mathrm{~Hz}), 2.63(\mathrm{dd}, 1 \mathrm{H}, J=4.12,12.95 \mathrm{~Hz}), 2.87(\mathrm{~d}, 1 \mathrm{H}$, $J=4.81 \mathrm{~Hz}), 7.07(\mathrm{~d}, 2 \mathrm{H}, J=8.25 \mathrm{~Hz}), 7.23(\mathrm{~d}, 2 \mathrm{H}, J=$ $8.25 \mathrm{~Hz})$.

4d : $0.87(\mathrm{~d}, 3 \mathrm{H}, J=6.87 \mathrm{~Hz}), 0.91(\mathrm{~d}, 3 \mathrm{H}, J=6.87$ $\mathrm{Hz}), 1.35-1.43(\mathrm{~m}, 1 \mathrm{H}), 1.55-1.65(\mathrm{~m}, 2 \mathrm{H}), 1.73-1.81(\mathrm{~m}$, 2H), 1.97-2.02 (m, 1H), 2.15-2.21 (m, 1H), $2.31(\mathrm{dd}, 1 \mathrm{H}$, $J=11.23,13.52 \mathrm{~Hz}), 2.65(\mathrm{dd}, 1 \mathrm{H}, J=4.36,13.52 \mathrm{~Hz})$, $2.86(\mathrm{~d}, 1 \mathrm{H}, J=4.13 \mathrm{~Hz}), 2.88(\mathrm{~d}, 1 \mathrm{H}, J=4.13 \mathrm{~Hz}), 7.06$ $(\mathrm{d}, 2 \mathrm{H}, J=8.48 \mathrm{~Hz}), 7.23(\mathrm{~d}, 2 \mathrm{H}, J=8.48 \mathrm{~Hz})$.

1.5 cis-2-(4-Chlorobenzyl)-cis-5-isopropyl-1-(1H-1, 2, 4triazol-1-ylmethyl)cyclopentanol (5a)

Under nitrogen atmosphere, $60 \%$ oily sodium hydride $(1.2 \mathrm{~g}, 30.0 \mathrm{mmol})$ was washed with hexane, and DMF $(20 \mathrm{ml})$ was added. 1, 2, 4-Triazole $(2.1 \mathrm{~g}, 30.4 \mathrm{mmol})$ was slowly added and the mixture was stirred for $1 \mathrm{hr}$. Oxirane (4a) $(5.0 \mathrm{~g}, 18.9 \mathrm{mmol})$ was added, and the mixture was stirred for $2 \mathrm{hr}$ at $80^{\circ} \mathrm{C}$.

After cooling to room temperature, the reaction mixture was poured into water and extracted with ethyl acetate. The ethyl acetate layer was washed with water and brine, and dried over anhydrous sodium sulfate. Purification of the adduct by silicagel column chromatography (hexane : ethyl acetate $=1: 1)$ gave $5 \mathbf{a}(5.0 \mathrm{~g}$, 79.3\%) as a solid. Recrystallization from hexane-ethyl acetate gave colorless crystals. $\mathrm{mp} 91-92^{\circ} \mathrm{C}$. IR $\nu_{\max }^{\mathrm{KBr}}$ $\mathrm{cm}^{-1}: 3250,2950,1490 .{ }^{1} \mathrm{H}$ NMR $\left(\mathrm{CDCl}_{3}\right) \delta \mathrm{ppm}:$ $0.95(\mathrm{~d}, 3 \mathrm{H}, J=6.88 \mathrm{~Hz}), 0.98(\mathrm{~d}, 3 \mathrm{H}, J=6.88 \mathrm{~Hz}), 1.40-$ $1.44(\mathrm{~m}, 1 \mathrm{H}), 1.49-1.53(\mathrm{~m}, 1 \mathrm{H}), 1.61-1.69(\mathrm{~m}, 4 \mathrm{H}), 1.98-$ $2.05(\mathrm{~m}, 1 \mathrm{H}), 2.24(\mathrm{dd}, 1 \mathrm{H}, J=4.58,13.75 \mathrm{~Hz}), 2.29$ (dd, $1 \mathrm{H}, J=10.54,13.75 \mathrm{~Hz}), 4.26(\mathrm{~d}, 1 \mathrm{H}, J=14.21 \mathrm{~Hz}), 4.41$ $(\mathrm{d}, 1 \mathrm{H}, J=14.21 \mathrm{~Hz}), 7.00(\mathrm{~d}, 2 \mathrm{H}, J=8.25 \mathrm{~Hz}), 7.20(\mathrm{~d}$, $2 \mathrm{H}, J=8.25 \mathrm{~Hz}), 8.03(\mathrm{~s}, 1 \mathrm{H}), 8.47(\mathrm{~s}, 1 \mathrm{H})$.

Azole $\mathbf{5 b}, \mathbf{5 c}$ and $\mathbf{5 d}$ were prepared in the same method as described above. Melting point, IR and NMR data of them were shown below.

cis-2-(4-Chlorobenzyl)-trans-5-isopropyl-1-(1H-1, 2, 4-triazol-1-ylmethyl)cyclopentanol (5b) : $\mathrm{mp} \quad 102-103^{\circ} \mathrm{C}$. IR $\nu_{\max }^{\mathrm{KBr}} \mathrm{cm}^{-1}: 3250,2940,1480 .{ }^{1} \mathrm{H}$ NMR $\left(\mathrm{CDCl}_{3}\right) \delta$ ppm : $0.96(\mathrm{~d}, 3 \mathrm{H}, J=6.42 \mathrm{~Hz}), 1.15(\mathrm{~d}, 3 \mathrm{H}, J=6.42$ $\mathrm{Hz}), 1.13-1.21(\mathrm{~m}, 1 \mathrm{H}), 1.26-1.36(\mathrm{~m}, 1 \mathrm{H}), 1.56-1.62(\mathrm{~m}$, $1 \mathrm{H}), 1.69-1.83(\mathrm{~m}, 3 \mathrm{H}), 1.89-1.95(\mathrm{~m}, 1 \mathrm{H}), 2.21(\mathrm{dd}, 1 \mathrm{H}$, $J=10.07,13.29 \mathrm{~Hz}), 2.26(\mathrm{dd}, 1 \mathrm{H}, J=5.04,13.29 \mathrm{~Hz})$, $4.15(\mathrm{~d}, 1 \mathrm{H}, J=13.75 \mathrm{~Hz}), 4.46(\mathrm{~d}, 1 \mathrm{H}, J=13.75 \mathrm{~Hz})$, $6.82(\mathrm{~d}, 2 \mathrm{H}, J=8.25 \mathrm{~Hz}), 7.16(\mathrm{~d}, 2 \mathrm{H}, J=8.25 \mathrm{~Hz}), 8.09$ (s, 1H), $8.64(\mathrm{~s}, 1 \mathrm{H})$.

trans-2-(4-Chlorobenzyl)-cis-5-isopropyl-1-(1 H-1, 2, 4-triazol-1-ylmethyl)cyclopentanol (5c) : $\mathrm{mp} 120-121^{\circ} \mathrm{C}$. IR $\nu_{\max }^{\mathrm{KBr}} \mathrm{cm}^{-1}: 3300,2950,1480 .{ }^{1} \mathrm{H}$ NMR $\left(\mathrm{CDCl}_{3}\right) \delta$ ppm : $0.75(\mathrm{~d}, 3 \mathrm{H}, J=6.88 \mathrm{~Hz}), 0.87(\mathrm{~d}, 3 \mathrm{H}, J=6.88$ $\mathrm{Hz}), 1.14-1.21(\mathrm{~m}, 1 \mathrm{H}), 1.47-1.54(\mathrm{~m}, 2 \mathrm{H}), 1.57-1.62(\mathrm{~m}$, $1 \mathrm{H}), 1.65-1.72(\mathrm{~m}, 1 \mathrm{H}), 1.74-1.81(\mathrm{~m}, 1 \mathrm{H}), 1.99-2.05(\mathrm{~m}$, 1H), $2.26(\mathrm{dd}, 1 \mathrm{H}, J=11.66,13.08 \mathrm{~Hz}), 3.04(\mathrm{dd}, 1 \mathrm{H}$, $J=3.43,13.08 \mathrm{~Hz}), 4.24(\mathrm{~d}, 1 \mathrm{H}, J=13.75 \mathrm{~Hz}), 4.35(\mathrm{~d}$, $1 \mathrm{H}, J=13.75 \mathrm{~Hz}), 7.05(\mathrm{~d}, 2 \mathrm{H}, J=8.25 \mathrm{~Hz}), 7.24(\mathrm{~d}, 2 \mathrm{H}$, $J=8.25 \mathrm{~Hz}), 8.03(\mathrm{~s}, 1 \mathrm{H}), 8.34(\mathrm{~s}, 1 \mathrm{H})$.

trans-2-(4-Chlorobenzyl)-trans-5-isopropyl-1-(1H-1,

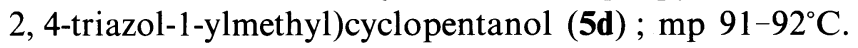
IR $\nu_{\max }^{\mathrm{KBr}} \mathrm{cm}^{-1}: 3200,2950,1480 .{ }^{1} \mathrm{H}$ NMR $\left(\mathrm{CDCl}_{3}\right) \delta$ ppm : $0.87(\mathrm{~d}, 3 \mathrm{H}, J=6.19 \mathrm{~Hz}), 1.00(\mathrm{~d}, 3 \mathrm{H}, J=6.19$ $\mathrm{Hz}), 1.24-1.36(\mathrm{~m}, 2 \mathrm{H}), 1.49-1.56(\mathrm{~m}, 1 \mathrm{H}), 1.60-1.78(\mathrm{~m}$, 2H), $1.75(\mathrm{dd}, 1 \mathrm{H}, J=11.91,12.83 \mathrm{~Hz}), 1.89-1.99(\mathrm{~m}$, $1 \mathrm{H}), 2.03-2.09(\mathrm{~m}, 1 \mathrm{H}), 2.47(\mathrm{dd}, 1 \mathrm{H}, J=2.75,12.83 \mathrm{~Hz}$ ), $4.36(\mathrm{~s}, 2 \mathrm{H}), 6.94(\mathrm{~d}, 2 \mathrm{H}, J=8.24 \mathrm{~Hz}), 7.18(\mathrm{~d}, 2 \mathrm{H}, J=$ $8.24 \mathrm{~Hz}), 8.01(\mathrm{~s}, 1 \mathrm{H}), 8.43(\mathrm{~s}, 1 \mathrm{H})$.

\subsection{Optical resolution of azoles $5 \boldsymbol{a}$ and $5 \mathrm{~b}$}

Azole isomer $5 \mathbf{a}$ or $\mathbf{5 b}$ was dissolved in methanol, and the objective compounds were collected fractionally by HPLC with chiral column according to following conditions. After removal of solvent, the residue was recrystallized from hexane-ethyl acetate to give optical pure crystal. Total four enantiomers were obtained. HPLC conditions : column, CHIRALCELL OD $(500 \times 10 \mathrm{~mm}$ i.d., DAICEL Chemical Industries, Ltd.); pump, HITACHI 638-30; eluent, hexane $:$ isopropanol $=15: 1$; 
Table 2 Melting points and specific rotations of enantiomers of azoles (5a) and (5b).

\begin{tabular}{ccc}
\hline Compound & $\mathrm{mp}\left({ }^{\circ} \mathrm{C}\right)$ & {$[\alpha]_{\mathrm{D}}^{20}$} \\
\hline$(+)-5 \mathbf{a}$ & $97-98$ & $+4.17^{\circ}(c=1.44, \mathrm{EtOH})$ \\
$(-)-5 \mathbf{a}$ & $97-98$ & $-3.27^{\circ}(c=1.23, \mathrm{EtOH})$ \\
$(+)-5 \mathbf{b}$ & $129-130$ & $+49.2^{\circ}(c=1.59, \mathrm{EtOH})$ \\
$(-)-5 \mathbf{b}$ & $129-130$ & $-46.8^{\circ}(c=1.82, \mathrm{EtOH})$ \\
\hline
\end{tabular}

Table 3 Antifungal activities of azole racemic diastereomers (5) in vitro.

\begin{tabular}{cccc}
\hline \multirow{2}{*}{ Compound } & \multicolumn{3}{c}{$\mathrm{EC}_{50}(\mu \mathrm{g} / \mathrm{ml})$} \\
\cline { 2 - 4 } & $\begin{array}{c}\text { Gibberella } \\
\text { fujikuroi }\end{array}$ & $\begin{array}{c}\text { Cochliobolus } \\
\text { miyabeanus }\end{array}$ & $\begin{array}{c}\text { Pyricularia } \\
\text { oryzae }\end{array}$ \\
\hline 5a & 0.05 & 0.4 & 0.08 \\
5b & 0.06 & 0.4 & 0.03 \\
5c & 0.9 & 1 & 0.5 \\
5d & 0.09 & 0.5 & 0.04 \\
\hline
\end{tabular}

flow rate, $10 \mathrm{ml} / \mathrm{min}$; detector, UV $268 \mathrm{~nm}$; injection volume, $15 \mathrm{mg} / 150 \mu 1$ (methanol).

The melting points and specific rotations of the enantiomers were shown in Table 2. X-ray crystal structure analysis was carried out to assign the absolute configuration.

\section{Fungicidal Test}

\subsection{Antifungal activity assay in vitro}

The each test compound was dissolved and diluted with DMSO, and then suspended in sterilized potato sucrose agar (PSA) medium to give prescribed concentrations (the final DMSO concentration was 1\%). The medium was poured in Petri dishes and was hardened. Mycelial discs (4 mm in diameter) of Gibberella fujikuroi ( $G$. fujikuroi), Cochliobolus miyabeanus ( $C$. miyabeanus) and Pyricularia oryzae (P. oryzae) grown on the PSA alone in advance were transferred to the PSA plates containing the various concentrations of each compound. After incubation for 3 days at $28^{\circ} \mathrm{C}$, the diameter of each colony was measured to determine the $\mathrm{EC}_{50}$ (the effective concentration of $50 \%$ inhibition of mycelial growth) value.

The $\mathrm{EC}_{50}$ values of azole racemic diastereomers (5) were shown in Table 3 and those of azole enantiomers of $\mathbf{5 a}$ and $\mathbf{5 b}$ were in Table 6 .

\subsection{Antifungal activity assay in vivo}

\subsection{1 "Bakanae" disease of rice}

The each test compound was dissolved in acetone, mixed with a detergent, Gramin S, and suspended in water (the final concentrations of acetone and Gramin S were 1 and $0.03 \%$, respectively). The suspension was diluted with water containing $1 \%$ of acetone and $0.03 \%$ of Gramin $\mathrm{S}$ to give concentrations of 300,75 and $18 \mu \mathrm{g} /$ $\mathrm{ml}$. Rice seeds $(9 \mathrm{~g})$ (cultivar: "Tanginbose" infected with $G$. fujikuroi) were soaked in $10 \mathrm{ml}$ of the suspension at $20^{\circ} \mathrm{C}$ for $24 \mathrm{hr}$. After being immersed in the water at $30^{\circ} \mathrm{C}$ for 3 days in order to hasten germination, the seeds were sowed in nursery soil and cultivated in a greenhouse for 2 weeks. Disease symptom of the seedlings was investigated and protective value was calculated as follows :

$$
\text { Protective value }(\%)=(1-T / C) \times 100
$$

where $T$ represents percentage of diseased seedlings on treated plants and $C$ represents that on untreated plants. Protective values were shown in Table 4.

\subsubsection{Brown spot of rice}

Chemical suspensions were prepared as describe above (2.2.1) except concentrations of acetone and Gramin S were 5 and $0.018 \%$, respectively. The suspension was sprayed on rice (cultivar : "Koshihikari") at the fifth leaf stage. After the plants were dried, aqueous spore suspensions of $C$. miyabeanus was inoculated by spraying. The seedlings were maintained in a greenhouse for 6 days, and then the disease spots on the leaf were counted to determine protective value, which was calculated as follows :

$$
\text { Protective value }(\%)=(1-T / C) \times 100
$$

where $T$ represents number of spots on treated plants and $C$ represents that on untreated plants. Protective values were shown in Table 5.

\section{Plant Growth Inhibitory Activity Assay}

Chemical suspensions prepared as describe above (2.2. 2) except for chemical concentration was $250 \mu \mathrm{g} / \mathrm{ml}$. Rice seeds ( $5 \mathrm{~g}$ ) (cultivar : "Koshihikari") were soaked at $20^{\circ} \mathrm{C}$ for $24 \mathrm{hr}$ in $5 \mathrm{ml}$ of the chemical suspension, then immersed in water at $30^{\circ} \mathrm{C}$ for 3 days. The seeds were sowed in nursery soil and cultivated in a greenhouse for 10 days. The plant growth inhibitory rate was determined by measuring the first sheath length and shown in Table 7.

\section{RESULTS AND DISCUSSION}

\section{Chemical Study}

The four azole racemic diastereomers (5) were synthesized by the method shown in Fig. 2. Isopropyl group was introduced into methyl 2-oxocyclopentanecarboxylate (1), the resulting product was subjected to Dieckmann recyclization reaction ${ }^{5)}$ to form methyl 3-isopropyl2-oxocyclopentanecarboxylate (2), and subsequently, 4-chlorobenzyl group was introduced, ${ }^{6}$ ) followed by hydrolysis and decarboxylation ${ }^{7}$ to obtain 2-(4chlorobenzyl)-5-isopropylcyclopentanone (3). To obtain four racemic diastereomers of 4-(4-chlorobenzyl)7-isopropyl-1-oxaspiro[2.4] heptane (4), two methods (A and B) were examined. Method A is a reaction which uses dimethylsulfoxonium methylide, ${ }^{8)}$ and method $\mathrm{B}$ is a 
method in which ketone (3) is converted to 2-(4chlorobenzyl)-5-isopropyl-1-methylenecyclopentane $\left(\mathbf{3}^{\prime}\right)$ through Wittig reaction ${ }^{9)}$ followed by oxidation. ${ }^{10)}$ The ratios of resulting diastereomers by these two methods were listed in Table 1. Method A gave oxirane isomer (4a) as a major product and method B gave oxirane isomer (4b) as a major product. The four oxirane isomers (4) were isolated individually and the relative configuration was estimated from NOE (nuclear overhauser effect) difference spectrum.

NOE was examined by irradiating methine proton of the isopropyl group, methylene proton of the oxirane ring, and methylene proton of the benzyl group of the oxirane isomers (4) individually. As shown in Fig. 3, NOE was not found for $\mathbf{4 a}$, NOE was found between $\mathrm{Hb}-\mathrm{l}$ of the isopropyl group and $\mathrm{Hb}-2$ of the oxirane ring for $\mathbf{4 b}$, and also found between Hc-3 of the oxirane ring and Hc-4 of the benzyl group for $4 \mathbf{c}$. NOE was found between $\mathrm{Hd}-\mathrm{l}$ of the isopropyl group and $\mathrm{Hd}-2$ of the oxirane ring, and between Hd-3 of the oxirane ring and Hd-4 of the benzyl group for $\mathbf{4 d}$.

Based on these results, the relative configuration of oxirane isomers (4) were estimated as shown in Fig. 3. The four oxirane isomers (4) were introduced to azoles (5). The relative configuration of azole isomers (5) was also estimated by NOE difference spectrum. The result of NOE by irradiation of the methine proton of the isopropyl group, the methylene proton of the triazolylmethyl group, and the methylene proton of the benzyl group of azole (5) was the same as that of oxirane (4). This result supports the estimation of relative configuration of four oxirane isomers.

$\mathrm{X}$-ray crystal structure analysis of (-)-5a was carried
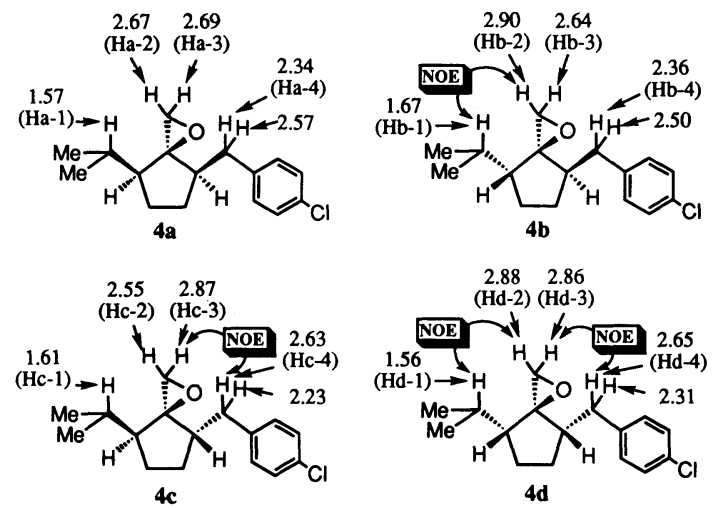

Fig. $3{ }^{1} \mathrm{H}$ NMR chemical shifts $(\delta \mathrm{ppm})$ and NOEs in oxirane (4).

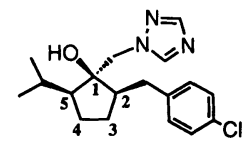

$(-)-(1 S, 2 R, 5 S)-5 \mathrm{a}$

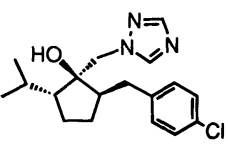

(-)-(1S, 2R, 5R)-5b
Fig. 4 Absolute configurations of (-)-5a and (-)-5b. out and its crystal structure was determined as follows : monoclinic, $P 2_{1}, a=23.592, b=8.448, c=9.973 \AA, \beta=$ $113.54^{\circ}, Z=4, R=0.0450$. It assigned the absolute configuration of the $(-)-5 \mathbf{a}$ as $(1 S, 2 R, 5 S)$. From analyses result of $(-)-5 \mathbf{a}$, the absolute configuration of (-)-5b was estimated as $(1 S, 2 R, 5 R)$ (Fig. 4). The relative configuration of azole isomer (5a) estimated by NOE difference spectrum was confirmed from this resultant.

\section{Antifungal and Plant Growth Inhibitory Activities}

In comparison of antifungal activity on G. fujikuroi in the in vitro test of the four azole racemic diastereomers, activities of $\mathbf{5 a}, \mathbf{5 b}$ and $\mathbf{5 d}$ were high but that of $\mathbf{5 c}$ was rather low. The same results were obtained in the tests on $C$. miyabeanus and $P$. oryzae. The activity of $5 \mathbf{a}$ on G. fujikuroi was higher about 20 times than that of 5c (Table 3). In the in vivo test on "Bakanae" disease at a concentration of $75 \mu \mathrm{g} / \mathrm{ml}$ of seed treatment, the activities of $\mathbf{5 a}$ and $\mathbf{5 b}$ were high, that of $\mathbf{5 d}$ was slightly lower than the formers, and that of $\mathbf{5 c}$ was the lowest in the four isomers. In the test on brown spot the same result was obtained (Tables 4 and 5). The result of the in vivo test correlated with that of the in vitro test. As an overall evaluation of the four azole racemic diastereomers with the three fungi ( $G$. fujikuroi, $C$. miyabeanus and $P$. oryzae), it is found that the activities of $\mathbf{5 a}$ and $\mathbf{5 b}$ are the highest, $\mathbf{5 d}$ is slightly lower, and $\mathbf{5 c}$ is the lowest.

Antifungal activity of enantiomers of $\mathbf{5 a}$ or $\mathbf{5 b}$ was clearly different between $(-)$ - and $(+)$-isomers. For both $\mathbf{5 a}$ and $\mathbf{5 b},(-)$-isomers were more active than $(+)$-isomers on G. fujikuroi, $C$. miyabeanus and $P$. oryzae. The activity of $(-)$-isomer of $\mathbf{5 a}$ was 330 times

Table 4 Control activities of azole racemic diastereomers (5) on "Bakanae" disease of rice by seed treatment.

\begin{tabular}{cccc}
\hline & \multicolumn{3}{c}{ Control (\%) } \\
\cline { 2 - 4 } Compound & \multicolumn{3}{c}{ Concentration $(\mu \mathrm{g} / \mathrm{ml})$} \\
\cline { 2 - 4 } & 300 & 75 & 18 \\
\hline 5a & 98.7 & 96.5 & 61.2 \\
5b & 99.6 & 97.5 & 52.1 \\
5c & 95.2 & 59.1 & 0.0 \\
5d & 97.5 & 76.8 & 9.7 \\
\hline
\end{tabular}

Table 5 Control activities of azole racemic diastereomers (5) on brown spot of rice by foliar application.

\begin{tabular}{cccc}
\hline & \multicolumn{3}{c}{ Control (\%) } \\
\cline { 2 - 4 } Compound & \multicolumn{3}{c}{ Concentration $(\mu \mathrm{g} / \mathrm{ml})$} \\
\cline { 2 - 4 } & 150 & 38 & 9 \\
\hline 5a & 100 & 84 & 86 \\
5b & 100 & 98 & 71 \\
5c & 92 & 49 & 25 \\
5d & 100 & 74 & 53 \\
\hline
\end{tabular}


Table 6 Antifungal activities of enantiomers of azoles (5a) and $(\mathbf{5 b})$ in vitro.

\begin{tabular}{cccc}
\hline \multirow{2}{*}{ Compound } & \multicolumn{3}{c}{$\mathrm{EC}_{50}(\mu \mathrm{g} / \mathrm{ml})$} \\
\cline { 2 - 4 } & $\begin{array}{c}\text { Gibberella } \\
\text { fujikuroi }\end{array}$ & $\begin{array}{c}\text { Cochliobolus } \\
\text { miyabeanus }\end{array}$ & $\begin{array}{c}\text { Pyricularia } \\
\text { oryzae }\end{array}$ \\
\hline$(+)-5 a$ & 10 & 6 & 1 \\
$(-)-5 a$ & 0.03 & 0.2 & 0.04 \\
$(+)-5 b$ & 6 & 3 & 0.7 \\
$(-)-5 b$ & 0.03 & 0.2 & 0.01 \\
\hline
\end{tabular}

higher than that of $(+)$-isomer on $G$. fujikuroi, 30 times on C. miyabeanus, and 25 times on P. oryzae (Table 6).

Based on these results, the correlation between the stereochemical structure of azole racemic diastereomers (5) and fungicidal activity was examined. Firstly, the relative configuration between hydroxy group and benzyl group of the four racemic diastereomers is correlated with activity as follows. $\mathbf{5 a}$ and $\mathbf{5 b}$, higher activity isomers, have cis-relative configuration, while $\mathbf{5 c}$ and $\mathbf{5 d}$, lower activity isomers, have trans-relative configuration. In other words, cis-relative configuration between hydroxy group and benzyl group is favorable for the high activity. Secondly, the relative configuration between hydroxy group and isopropyl group is correlated with activity. The activity of $\mathbf{5 a}$ is not different from that of $\mathbf{5 b}$, therefore the steric effect of isopropyl group is not clear with those two isomers. However, the fact that the activity of 5d is higher than that of 5c, suggests that trans-isopropyl group is more favorable than cis-isopropyl group for the high activity. Azole isomer (5d) shows nearly the same activity as $\mathbf{5 a}$ and $\mathbf{5 b}$ in spite of trans-relative configuration between hydroxy group and benzyl group, which is unfavorable configuration for the high activity. We had prepared a series of derivatives which have other alkyl group (e.g., $\mathrm{Me}, \mathrm{Et}, \mathrm{Pr}, \mathrm{Bu}$ and $\mathrm{Pen}$ ) instead of isopropyl group of $\mathbf{5 a}$ and $\mathbf{5 b}$. In comparison with fungicidal activity among the derivatives, trans-alkyl group showed higher activity than cis-alkyl group. ${ }^{11)}$ Although the reason for the high activity of $\mathbf{5 a}$, cisisopropyl group, as well as $\mathbf{5 b}$, trans-isopropyl group, is not clear, the branched-chain of isopropyl group of both $\mathbf{5 a}$ and $\mathbf{5 b}$ likely contributes to the interaction with the

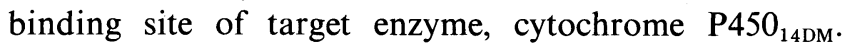
Enantiomers (-)-5a and (-)-5b were more active than $(+)$-isomers in fungicidal activity. This clear stereochemical discrimination will become important when receptor model is considered.

Among the azole racemic diastereomers, 5a, 5b and 5c are little active on plant growth regulatory effect on rice, but $\mathbf{5 d}$ is slightly active in the first sheath growth inhibition (Table 7). It is known that azole fungicide causes biosynthesis inhibition of a plant hormone, gibberellin, and suppresses elongation of plant cells. Uniconazole ${ }^{12)}$ and paclobutorazole ${ }^{13)}$ are used as plant growth regula-
Table 7 Plant growth inhibitory activities of azole racemic diastereomers (5) on rice by seed treatment.

\begin{tabular}{cc}
\hline & Growth rate $^{\text {a) }}$ to control (\%) \\
\cline { 2 - 2 } & Concentration $250 \mu \mathrm{g} / \mathrm{ml}$ \\
\hline 5a & 98.3 \\
5b & 90.7 \\
$\mathbf{5 c}$ & 91.7 \\
$\mathbf{5 d}$ & 82.5 \\
\hline a) Measured the first sheath length in 30 replications. \\
b) Treated with $250 \mu \mathrm{g} / \mathrm{ml}$ solution for $24 \mathrm{hr}$ before \\
emergence.
\end{tabular}

tor. The slight sheath growth inhibition found on $\mathbf{5 d}$ is assumed as a result of gibberellin biosynthesis inhibition based on morphological observation. Further studies will be needed to clarify the correlation between the structure of a series of azolylmethylcyclopentanol derivatives and plant growth inhibitory activity.

\section{ACKNOWLEDGMENTS}

We would like to express our thanks to Dr. Chizuko Kabuto of Tohoku University, who was kind enough to carry out the X-ray crystal structural analysis.

\section{REFERENCES}

1) W. Köller : Pestic. Sci. 18, 129 (1987)

2) Y. Funaki, Y. Ishiguri, T. Kato \& S. Tanaka : J. Pesticide Sci. 9, 229 (1984)

3) A. Murabayashi, M. Masuko, M. Niikawa, N. Shirane, T. Furuta, Y. Hayashi \& Y. Makisumi : J. Pesticide Sci. 16, 419 (1991)

4) H. Chuman, A. Ito, T. Saishoji \& S. Kumazawa : "Classical and 3D QSAR in Agrochemistry: ACS Symposium Series 606," ed. by C. Hansch \& T. Fujita, Am. Chem. Soc., Washington, D.C., p. 171, 1995

5) K. Sisido, K. Utimoto \& T. Isida : J. Org. Chem. 29, 2781 (1964)

6) F. Elsinger: Org. Synth. Coll. 4, 76 (1963)

7) H. O. House: "Modern Synthetic Reactions," 2nd ed., W. A. Benjamin, California, p. 515, 1972

8) E. J. Corey \& M. Chaykovsky: J. Am. Chem. Soc. 87, 1353 (1965)

9) R. Greenwald, M. Chaykovsky \& E. J. Corey: J. Org. Chem. 28, 1128 (1963)

10) L. A. Paquette \& J. H. Barrett: Org. Synth. Coll. 5, 476 (1973)

11) A. Ito, T. Saishoji, S. Kumazawa \& H. Chuman : "Threedimensional Structure and Fungicidal Activity of Related Compounds of Metconazole, a Novel Azole Fungicide," 22nd Symposium on Structure-Activity Relationships, Tokyo, p. 230, 1994

12) K. Izumi, I. Yamaguchi, A. Wada, H. Oshio \& N. Takahashi : Plant Cell Physiol. 25, 611 (1984)

13) B. Sugavanam : Pestic. Sci. 15, 296 (1984) 


\section{要 約}

イプコナソールの立体異性体の合成と光れらの殺菌 および植物生長抑制活性

伊藤篤史, 最勝寺俊英, 熊沢 智 水稲種子消毒剂であるイプコナゾール， $(1 R S, 2 S R$,

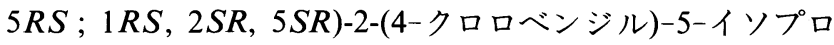
ピル-1-(1H-1, 2, 4-トリアゾール-1-イルメチル)シクロペ ンタノールの有効成分である 2 種類のジアステレオ異性体

$5 \mathbf{a}, 5 \mathbf{b}$ と他の 2 種類のジアステレオ異性体 $(1 R S, 2 R S$,
$5 R S)-5 \mathrm{c},(1 R S, 2 R S, 5 S R)-5 \mathrm{~d}$ を合成し，それらの殺菌お よび植物生長抑制活性を調べた. In vitro 試験でのイネばか 苗病菌，イネごま葉枯病菌，イネいもち病菌に対する各ジ アステレオ異性体の殺菌活性の比較では， $\mathbf{5 a}, \mathbf{5 b}$ および $\mathbf{5 d}$ が高い活性を示した. In vivo 試験では, 5d の活性が, 5a と 5b の活性より少し低下し, 活性の差がみられた。イネ種子 処理による植物生長抑制活性試験では, 5d に弱いながら節 間伸長抑制活性がみられた. $5 \mathbf{a}$ と $\mathbf{5 b}$ の光学異性体間の in vitro 試験での殺菌活性比較においては，各（一）体はそれ ぞれの各 $(+)$ 体に比べ活性が高かった。 